\title{
Patterns of left ventricular remodeling among patients with essential and secondary hypertension
}

\author{
DAN RADULESCU ${ }^{1}$, LAURENTIU STOICESCU ${ }^{2}$, \\ ELENA BUZDUGAN ${ }^{3}$, VALER DONCA ${ }^{4}$
}

Associate Professor of Medicine, MD Cardiology, PhD, Department of Cardiology, Vth Medical Clinic, University of Medicine and Pharmacy "Iuliu Hatieganu", ClujNapoca, Romania. ${ }^{2} U$ niversity Assistant, MD Cardiology, Department of Cardiology, Vth Medical Clinic, University of Medicine and Pharmacy "Iuliu Hatieganu", ClujNapoca, Romania. ${ }^{3}$ Senior Lecturer, MD cardiology, Department of Cardiology, Vth Medical Clinic, University of Medicine and Pharmacy "Iuliu Hatieganu", ClujNapoca, Romania.

${ }^{4}$ Senior Lecturer, MD cardiology and geriatrics, Department of Geriatrics, Vth Medical Clinic University of Medicine and Pharmacy "Iuliu Hatieganu", Cluj-Napoca, Romania.

Corresponding author for proof and reprints:

Dr. Laurentiu Stoicescu, MD, V th Medical Clinic, Department of Cardiology, 11 Tabacarilor Street, ClujNapoca, Romania, 400139 (postal code), 00-40-264437050 (phone number: 0040744488436) E-mail : stoicescul@yahoo.

\begin{abstract}
Background: High blood pressure causes left ventricular hypertrophy, which is a negative prognostic factor among hypertensive patients. Aim: To assess left ventricular geometric remodeling patterns in patients with essential hypertension or with hypertension secondary to parenchymal renal disease. Material and Methods: We analyzed data from echocardiograms performed in 250 patients with essential hypertension (150 females) and 100 patients with secondary hypertension (60 females). The interventricular septum and the left ventricular posterior wall thickness were measured in the parasternal long-axis. Left ventricular mass was calculated using the Devereaux formula. Results: The most common remodeling type in females and males with essential hypertension were eccentric and concentric left ventricular hypertrophy (cLVH), respectively. Among patients with secondary arterial hypertension, $c L V H$ was most commonly observed in both genders. The prevalence of left ventricular hypertrophy was higher among patients with secondary hypertension. The left ventricular mass index and the relative left ventricular wall thickness were higher in males and also in the secondary hypertension group. Age, blood pressure values and the duration of hypertension, influenced remodeling patterns. Conclusions: We documented a higher prevalence of LVH among patients with secondary hypertension. The type of ventricular remodeling depends on gender, age, type of hypertension, blood pressure values and the duration of hypertension.
\end{abstract}

(Rev Med Chile 2013; 141: 1520-1527).

Key words: Hypertension; Hypertension, renal; Hypertrophy, left ventricular; Ventricular remodeling.

\section{Patrones de remodelación ventricular en pacientes con hipertensión arterial primaria y secundaria}

Antecedentes: La hipertensión arterial causa hipertrofia ventricular izquierda, un factor de mal pronóstico en pacientes hipertensos. Objetivo: Evaluar patrones de remodelación ventricular en pacientes con hipertensión arterial esencial y secundaria a daño renal. Material y Métodos: Análisis de ecocardiogramas efectuados a 250 pacientes con hipertensión arterial primaria (150 mujeres) y 100 pacientes con hipertensión secundaria (60 mujeres). Se midió el grosor del septum interventricular y de la pared ventricular posterior. La masa ventricular izquierda se calculó usando la fórmula de Devereaux. Resultados: Los tipos más frecuentes de remodelación 
Hypertension and left ventricular remodeling - D. Radulescu et al

ventricular en mujeres y hombres con hipertensión esencial fueron la hipertrofia ventricular excéntrica y concéntrica, respectivamente. En pacientes con hipertensión arterial secundaria, la hipertrofia concéntrica fue más frecuente. La prevalencia de hipertrofia ventricular izquierda fue más alta en pacientes con hipertensión secundaria. El indice de masa ventricular izquierda y el grosor relativo de la pared ventricular izquierda fueron mayores en pacientes con hipertensión secundaria. La edad, los valores de presión arterial y la duración de la hipertensión influyeron en los patrones de remodelación. Conclusiones: Documentamos una mayor prevalencia de hipertrofia ventricular izquierda en pacientes con hipertensión secundaria. El tipo de remodelación depende de la edad, género, tipo de hipertensión, valores de presión arterial y duración de la hipertensión.

$\mathrm{D}$ ifferent studies, including the Framingham Heart, have documented that an increased left ventricular mass represents an independent negative prognostic factor concerning cardiovascular morbidity and mortality ${ }^{1-5}$. The presence and degree of left ventricular hypertrophy (LVH) and also the type of remodeling depend not only on the duration of hypertension and the values of blood pressure but also on different factors: sex, associated obesity, racial and genetic parameters. If these factors have been studied in patients with essential arterial hypertension, they were less studied in patients with secondary hypertension. Echocardiography is an accurate and relative inexpensive method to determine the existence of left ventricular hypertrophy and the type of remodeling ${ }^{6-10}$.

The purpose of our study was to assess the existence of left ventricular hypertrophy and the pattern of left ventricular remodeling in a group of population with essential arterial hypertension, compared to a group with secondary hypertension to chronic renal parenchymal diseases. We also tried to assess the influence of different factors (blood pressure values, the duration of hypertension, gender) on the pattern of left ventricular remodeling. Secondary objective was to correlate left ventricular (LV) remodeling patterns and different parameters such as left ventricular ejection fraction and systemic vascular resistance and the pattern of LV remodeling with the alteration of the LV diastolic function in the two groups.

\section{Material and Methods}

The essential hypertension group consisted of 250 patients older than 18 years, mainly from our outpatient clinic, checked-up in the period 2000-2012. The patients had a definite diagnosis of essential arterial hypertension, for more than 12 months, established on standard criteria. They were on no regular antihypertensive drugs. Patients with associated cardiovascular diseases, diabetes or other diseases generating $\mathrm{LVH}$, were excluded. Patients with secondary forms of hypertension were also ruled out.

The secondary hypertension group consisted of 100 patients older than 18 years, mainly from our outpatient and inpatient clinic, diagnosed with hypertension secondary to renal parenchymal diseases, documented at renal biopsy (secondary to chronic glomerulo-and pyelo-nephritis) and followed-up in the period 2000-2012. All had a satisfactory renal function with normal serum urea and creatinine. Patients with essential arterial hypertension or associated cardiovascular diseases, diabetes or other diseases generating $\mathrm{LVH}$, were excluded.

All patients were evaluated clinically, including vital signs, by the same physician, before the echocardiographic examination was completed.

\section{Echocardiographic examination}

It was performed with an Aloka 2000 ultrasound machine (Aloka, Japan), with a $3.5 \mathrm{MHz}$ transducer, the $\mathrm{M}$ and 2D-mode exams being done in the morning, with the patient in the left lateral decubitus. We measured the interventricular septum and the left ventricular posterior wall in parasternal long-axis, the left ventricular mass being calculated according to Devereaux ${ }^{6}$ : LVM $=1.04\left[(\mathrm{IVSd}+\mathrm{PWd}+\mathrm{LVDD})^{3}-\mathrm{LVDD}^{3}\right]-13.6 \mathrm{~g}$. The left ventricular mass index (LVMI) resulted by dividing LVM to the body surface (11). LVH was defined by the criteria: LVMI $>134 \mathrm{~g} / \mathrm{m}^{2}$ in 
males, and $>110 \mathrm{~g} / \mathrm{m}^{2}$ in women. The relative wall thickness (RWT) was deducted from the formula PWd + IVSd/LVDD. According to Ganau ${ }^{8}$, we defined 4 geometric remodeling types:

- The normal geometry (NG) was defined as no $\mathrm{LVH}$ with $\mathrm{RWT}<0.45$.

- The concentric hypertrophy (cLVH) was defined as LVH with RWT $\geq 0.45$.

- The eccentric hypertrophy (eLVH) was defined as $\mathrm{LVH}$ with $\mathrm{RWT}<0.45$.

- The concentric remodeling (CR) was defined as no $\mathrm{LVH}$ with $\mathrm{RWT} \geq 0.45$.

A subgroup of the $\mathrm{cLVH}$ patients was represented by those with asymmetric LVH (IVSd/ PWd $>1.5$ ).

The ejection fraction of the left ventricle was calculated using the Teicholz formula, and the systemic vascular resistance in conformity with the usual formula: SVR $($ dynes $\times \mathrm{s} / \mathrm{cm} 5)=(80$ $\times \mathrm{MAP}) / \mathrm{CO}$, where MAP represents the mean arterial pressure and $\mathrm{CO}$ the cardiac output. The left ventricular diastolic function was assessed by measuring the transmitral flow, the Doppler being parallel with the mitral flow with the cursor placed at the level of the mitral anulus in order to detect the maximal velocity of the $\mathrm{E}$ (Emax) and A waves (Amax). The Emax/Amax ratio, the pressure half time of the E wave (PHT) and the isovolumic relaxation time (IVRT) were also calculated.

\section{Statistical analyses}

We used the independent t-tests and one way (one-way) analysis of variance (ANOVA) tests to document differences between groups, for normally distributed variables and the Mann- Whitney test for skewed distribution. We expressed data as mean with standard deviation. We assessed univariate relations by Pearsons' correlation coefficients and we also used multiple regression analysis. The significance level of $\mathrm{p}$ was 0.05 . We used STATISTICA 5.0 for Windows.

\section{Results}

The clinical characteristics of the essential arterial hypertension and secondary renal parenchymal hypertension are presented in Tables 1 and 2 . As can be seen female patients prevailed over male patients. The age was similar for the 2 groups, but disease duration varied much. The patients with essential arterial hypertension were predominantly

Table 1. Characteristics of the essential arterial hypertension group

\begin{tabular}{|lccc|}
\hline Parameter & Females & Males & p females vs males \\
Number (patients) & 150 & 100 & $>0.05$ \\
HT stage 1* & $45(30 \%)$ & $35(35 \%)$ & $>0.05$ \\
HT stage 2* & $55(36.66 \%)$ & $50(50 \%)$ & $>0.05$ \\
HT stage 3* & $50(33.34 \%)$ & $15(15 \%)$ & \\
\hline
\end{tabular}

$\mathrm{HT}=$ hypertension. *Classification of blood pressure levels $(\mathrm{mmHg})$ according with $2013 \mathrm{ESH} / \mathrm{ESC}$ Guidelines for the management of arterial hypertension.

Table 2. Characteristics of the arterial hypertension of renal parenchymal origin group

\begin{tabular}{|lccc|}
\hline Parameter & Females & Males & p females vs males \\
\hline Number & 60 & 40 & \\
HT stage 1* & $5(8.33 \%)$ & $2(5 \%)$ & $>0.05$ \\
HT stage 2* & $21(35 \%)$ & $13(32.5 \%)$ & $>0.05$ \\
HT stage 3* & $34(56.67 \%)$ & $25(62.5 \%)$ & $>0.05$ \\
\hline
\end{tabular}

$\mathrm{HT}=$ hypertension. * Classification of blood pressure levels $(\mathrm{mmHg})$ according with $2013 \mathrm{ESH} / \mathrm{ESC}$ Guidelines for the management of arterial hypertension. 
Hypertension and left ventricular remodeling - D. Radulescu et al

in stage 2, whereas patients with renal parenchymal hypertension were mostly in stage 3 .

In tables 3 and 4 are presented the echocardiographic parameters, the remodeling patterns and the LVH prevalence for the different stages of hypertension in both groups. As can be seen the LVMI and RWT were greater in males than in females and also in the secondary renal parenchymal hypertension group compared to the essential hypertension population. The most frequent remodeling type in females with essential hypertension was the eLVH followed by the cLVH, the NG and CR, whereas in males the cLVH surpassed in frequency the eLVH. In the secondary arterial hypertension of renal parenchymal origin group, the most frequent encountered remodeling type both in females and males was the cLVH followed by eLVH, CR and NG. The prevalence of LVH in all three hypertension stages was higher in the secondary arterial hypertension group compared to the essential hypertension group.

As can be seen in tables 5 and 6, the age of the patients, the systolic and diastolic blood pressure values and the duration of hypertension played an important role in the LV remodeling pattern, both in the essential hypertension group and in the secondary arterial hypertension, both in females and males. The highest LV ejection fractions and

Table 3. Echocardiographic parameters in the essential arterial hypertension group

\begin{tabular}{|c|c|c|c|}
\hline Parameter & Females (150) & Males (100) & p females vs males \\
\hline LVMI, $\mathrm{g} / \mathrm{m}^{2}$ & $124.4 \pm 32.2$ & $139.7 \pm 36.6$ & $<0.01$ \\
\hline RWT & $0.42 \pm 0.08$ & $0.43 \pm 0.09$ & 0.07 \\
\hline $\begin{array}{l}\text { Remodeling type } \\
\text { eLVH } \\
\text { CLVH } \\
\text { NG } \\
\text { CR }\end{array}$ & $\begin{array}{l}52(34.66 \%) \\
47(31.33 \%) \\
34(22.67 \%) \\
17(11.33 \%)\end{array}$ & $\begin{array}{r}33(33 \%) \\
37(37 \%) \\
23(23 \%) \\
7 \quad(7 \%)\end{array}$ & \\
\hline Prevalence of LVH in stage I HT & $52(34.67 \%)$ & $33(33 \%)$ & \\
\hline Prevalence of LVH in stage II HT & $110(73.34 \%)$ & $80(80 \%)$ & \\
\hline Prevalence of LVH in stage III HT & $145(96.67 \%)$ & $96(96 \%)$ & \\
\hline
\end{tabular}

$\mathrm{LVMI}=$ left ventricular mass index. RWT $=$ relative wall thickness. eLVH $=$ eccentric $\mathrm{LVH} . \mathrm{CLVH}=$ concentric $\mathrm{LVH} . \mathrm{NG}=$ normal geometry. $\mathrm{CR}=$ concentric remodeling.

Table 4. Echocardiographic parameters in the renal parenchymal origin arterial hypertension group

\begin{tabular}{|c|c|c|c|}
\hline Parameter & Females (60) & Males (40) & p females vs males \\
\hline LVMI, g/m² & $125.4 \pm 32.3$ & $140.7 \pm 36.7$ & $<0.01$ \\
\hline RWT & $0.43 \pm 0.09$ & $0.44 \pm 0.10$ & 0.07 \\
\hline $\begin{array}{l}\text { Remodeling type } \\
\text { eLVH } \\
\text { CLVH } \\
\text { NG } \\
\text { CR }\end{array}$ & $\begin{array}{c}16(26.6 \%) \\
27(45 \%) \\
7(11.6 \%) \\
10(16.6 \%)\end{array}$ & $\begin{array}{c}11(27.5 \%) \\
22(55 \%) \\
1(2.5 \%) \\
6(15 \%)\end{array}$ & \\
\hline Prevalence of LVH in stage I HT & $18(30 \%)$ & $19(47.5 \%)$ & \\
\hline Prevalence of LVH in stage II HT & $48(80 \%)$ & $36(90 \%)$ & \\
\hline Prevalence of LVH in stage III HT & $59(98.34 \%)$ & $39(97.5 \%)$ & \\
\hline
\end{tabular}

$\mathrm{LVMI}=$ left ventricular mass index. RWT = relative wall thickness. eLVH = eccentric $\mathrm{LVH} . \mathrm{CLVH}=$ concentric $\mathrm{LVH} . \mathrm{NG}=$ normal geometry. $\mathrm{CR}=$ concentric remodeling. 
Table 5. Echocardiographic-haemodynamic characteristics in the $\mathbf{4} \mathrm{LV}$ remodeling types in patients with essential arterial hypertension

\begin{tabular}{|lcccc|}
\hline Parameter & eLVH & CLVH & NG & CR \\
\hline Age (years) & $54.7 \pm 2.8$ & $53.3 \pm 3.5$ & $50.04 \pm 3.4$ & $51.7 \pm 4.2$ \\
\hline BPs (mm Hg) & $174.5 \pm 7.5$ & $180.3 \pm 8.8$ & $168.7 \pm 8.8$ & $178.6 \pm 10.6$ \\
\hline BPd (mm Hg) & $105.6 \pm 4.8$ & $109.4 \pm 5.7$ & $102.4 \pm 6.6$ & $101.7 \pm 7.6$ \\
\hline Duration of HT (years) & $9.9 \pm 1.5$ & $10.8 \pm 1.4$ & $8.5 \pm 1.6$ & $10.3 \pm 1.3$ \\
LV ejection fraction (\%) & $66.30 \pm 13.7$ & $64.07 \pm 12.3$ & $55.3 \pm 6.7$ & $55.74 \pm 7.9$ \\
SVR (dyne*.sec* cm $\left.^{-5}\right)$ & $2046.97 \pm 460.4$ & $1824.1 \pm 722.7$ & $1572.9 \pm 61.1$ & $2819.5 \pm 159.1$ \\
\hline Altered diast function (\%) & $152(89.4 \%)$ & $148(89.6 \%)$ & $52(45.2 \%)$ & $33(66 \%)$ \\
\hline
\end{tabular}

$\mathrm{BP}=$ blood pressure. $\mathrm{HT}=$ hypertension. $\mathrm{SVR}=$ systemic vascular resistance.

Table 6. Echocardiographic-haemodynamic characteristics in the $4 \mathrm{LV}$ remodeling types in patients with renal parenchymal origin arterial hypertension

\begin{tabular}{|lcccc|}
\hline Parameter & eLVH & CLVH & NG & CR \\
\hline Age (years) & $52.5 \pm 2.6$ & $51.1 \pm 3.3$ & $48.2 \pm 3.2$ & $49.5 \pm 4$ \\
BPs (mm Hg) & $175.6 \pm 7.6$ & $181.4 \pm 8.9$ & $169.8 \pm 8.9$ & $179.7 \pm 10.7$ \\
BPd (mm Hg) & $106.7 \pm 4.9$ & $110.5 \pm 5.8$ & $103.5 \pm 6.7$ & $102.8 \pm 7.6$ \\
Duration of HT (years) & $7.8 \pm 1.3$ & $8.6 \pm 1.2$ & $6.3 \pm 1.4$ & $8.1 \pm 1.1$ \\
LV ejection fraction (\%) & $66.90 \pm 13.8$ & $65.07 \pm 12.4$ & $56.3 \pm 6.8$ & $56.74 \pm 8.1$ \\
SVR (dyne*.sec* ${ }^{-5}$ ) & $2047.99 \pm 370.5$ & $1910.1 \pm 729.8$ & $1610.9 \pm 66.1$ & $2920.6 \pm 160.2$ \\
\hline Altered diast. function (\%) & $49(90.7 \%)$ & $89(90.8 \%)$ & $9(56.2 \%)$ & $22(68.7 \%)$ \\
\hline
\end{tabular}

$\mathrm{BP}=$ blood pressure. $\mathrm{HT}=$ hypertension. $\mathrm{SVR}=$ systemic vascular resistance.

systemic vascular resistances were encountered in the eLVH, followed by the cLVH population. The diastolic function was altered preponderantly in the eLVH and cLVH groups, more severely in the

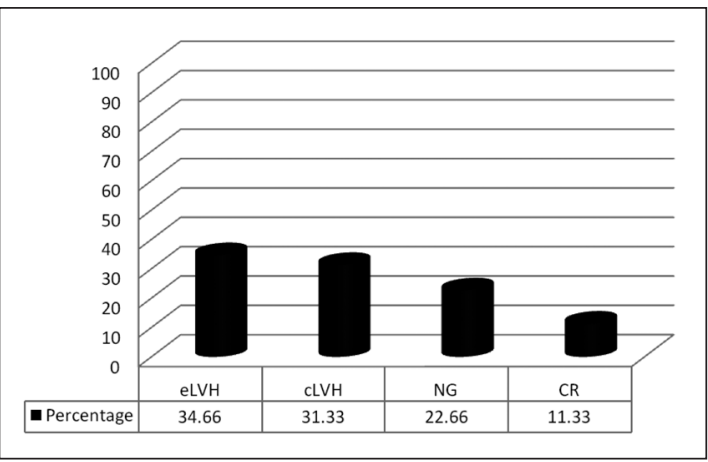

Figure 1. Remodeling of the left ventricle in females with essential hypertension. arterial hypertension of renal parenchymal origin population. We documented an increased SVR in $\mathrm{CR}$ groups probably due to an inappropriate vascular regulation mechanism (Figures 1-4).

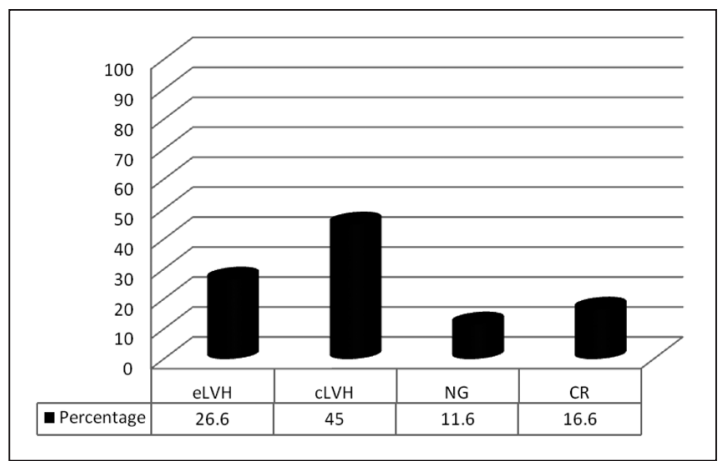

Figure 2. Remodeling of the left ventricle in females with secondary hypertension. 
Hypertension and left ventricular remodeling - D. Radulescu et al

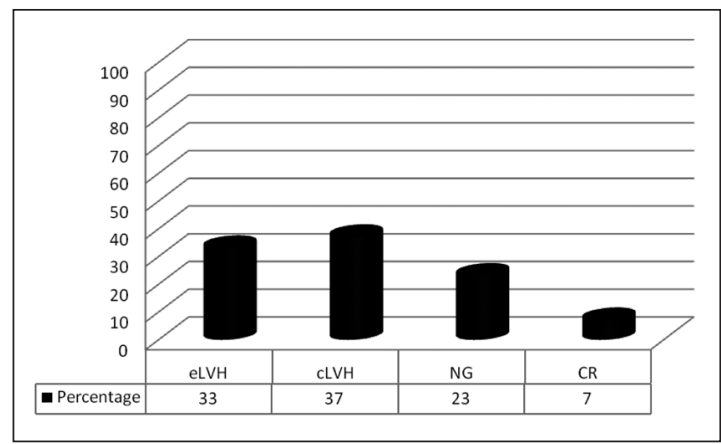

Figure 3. Remodeling of left ventricle in males with essential hypertension.

\section{Discussion}

The LV remodeling patterns were documented in the past in patients with essential arterial hypertension in studies like VITAE or LIFE ${ }^{9,12}$, but our study is the first one to investigate the LV prevalence and remodeling patterns in parallel in two populations: patients with essential arterial hypertension and patients with secondary arterial hypertension, generated by renal parenchymal diseases. Both groups were on no systematic antihypertensive drugs, as such medication can influence the $\mathrm{LVH}^{13,15}$. The patients with secondary arterial hypertension had a near normal renal function, the serum urea and creatinine being in normal limits. Other secondary causes of arterial hypertension were excluded from both groups, and also patients with other diseases generating $\mathrm{LVH}$ (coronary heart disease, diabetes, obesity, valvular heart disease, etc.) were ruled out.

The prevalence of LVH was higher in the secondary arterial hypertension compared to the essential hypertension group for all males and for females in stage II or III of hypertension. The most frequent remodeling type in females with essential hypertension was the eLVH, whereas in males the cLVH surpassed in frequency the eLVH. In the secondary arterial hypertension, the most frequent encountered remodeling type both in females and males was the cLVH. Different studies have revealed a high incidence of eLVH in patients with essential arterial hypertension, even in mild to moderate forms ${ }^{16,27,28}$. Our study has documented that in arterial hypertension secondary to renal parenchymal diseases, the most frequent form of remodeling is the cLVH, in both sexes.

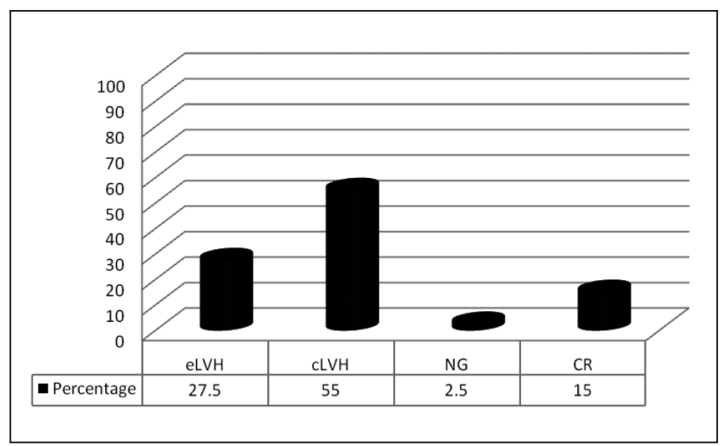

Figure 4. Remodeling of left ventricle in males with secondary hypertension.

We documented that the age and gender of the patients, the systolic and diastolic blood pressure values and the duration of hypertension played an important role in the LV remodeling pattern, in both groups, both females and males. Many studies have shown the effect of age on left ventricular remodeling in hypertensive patients, but also in normotensive individuals ${ }^{17-21}$. Concerning the gender of our patients, we found out a greater $\mathrm{LVH}$ with predominant cLVH in males compared to females, not only in the essential hypertension ${ }^{22}$, but also in the secondary arterial hypertension of renal parenchymal origin population ${ }^{29}$. The effect of hypertension severity and duration on the degree and type of LVH documented in our study, was revealed also by previous studies, including the study by $\mathrm{Chen} \mathrm{CH}$ et $\mathrm{al}^{23,24}$. We documented this aspect not only in the essential hypertension group but also in the secondary arterial hypertension one showing a direct correlation between hyprtension stage and prevalence of $\mathrm{LVH}$.

As expected, we encountered the highest LV ejection fractions and systemic vascular resistances in the eLVH, followed by the cLVH population. An interesting observation of our study is an altered diastolic function preponderantly in the eLVH and cLVH groups, more severely in the arterial hypertension of renal parenchymal origin, population, an important finding since resting diastolic function and left ventricular mass influence the exercise capacity in hypertensive patients ${ }^{25,26}$.

\section{Conclusion}

We documented a high prevalence of LVH in all 3 stages of hypertension, higher in the secondary 
arterial hypertension of renal parenchymal origin group compared to the essential hypertension group both for males and for females in stage II or III of hypertension. The most frequent remodeling type in females with essential hypertension was the eLVH followed by the cLVH, whereas in males the cLVH surpassed in frequency the eLVH. In the secondary arterial hypertension group, the most frequent encountered remodeling type both in females and males was the cLVH followed by eLVH. Another observation is that the age and gender of the patients, the systolic and diastolic blood pressure values and the duration of hypertension, all played an important role in the LV remodeling pattern, in both groups, both in females and males. We encountered the highest LV ejection fractions and systemic vascular resistances in the eLVH, followed by the cLVH population. An interesting observation of our study is an altered diastolic function preponderantly in the eLVH and cLVH groups, more severely in the arterial hypertension of renal parenchymal origin population.

\section{References}

1. Bikkina M MD MPH, Levy DMD, Evans JC MPH, Larson MG ScD, Benjamin EJ MD ScM, Wolf PA MD, et al. Left ventricular mass and risk of stroke in an elderly cohort, the Framingham study. JAMA 1994; 272: 33-6.

2. Devereaux RB, Roman MJ. Left ventricular hypertrophy in hypertension: stimuli, patterns and consequences. Hypertension Res 1999; 22: 1-9.

3. Kannel WB. Framingham study insights into hypertensive risks of cardiovascular disease. Hypertens Res 1995; 18: 181-96.

4. Kannel WB. Left ventricular hypertrophy as a risk factor. J Hypertension 1991; 9 (2): S3-9.

5. Levy D, Anderson KM, Savage DD, Balkus SA, Kannel WB, Castelli WP, et al. Risk of ventricular arrhythmias in left ventricular hypertrophy: The Framingham Heart Study. Am J Cardiol 1987; 60: 560-5.

6. Devereaux RB, Reichek N. Echocardiographic determination of left ventricular mass in men. Circulation 1977; 55: 613-8.

7. Devereaux RB. Detection of left ventricular hypertrophy by M-mode echocardiography. Anatomic validation, standardization and comparison to other methods. Hypertension 1987; 9 Suppl II: II19-26.

8. Ganau A, Devereux RB, Roman MJ, de Simone G, Pickering TG, Saba PS, et al. Patterns of left ventricular hypertrophy and geometric remodeling in essential hypertension. J Am Coll Cardiol 1992; 19: 1550-8.

9. Coca A, Gabriel R, de la Figuera M, López-Sendón JL, Fernández R, Sagastagoitia JD, et al. The impact of different echocardiographic diagnostic criteria on the prevalence of left ventricular hypertrophy in essential hypertension: the VITAE study. J Hypertens 1999; 17: 1471-80.

10. Muiesan ML, de Simone G, Ganau A, Longhini C, Verdecchia P, Mancia G, et al. Reliability and limitations of echocardiographic measurements of left ventricular mass for risk stratification and follow-up in single patients: the RES trial. J Hypertens 1999; 17: 1955-64.

11. Dubious D, Dubious F. A formula to estimate the approximate surface area if height and weight are known. Arch Intern Med 1916; 17: 863-71.

12. Wachtell K, Bella JN, Liebson PR, Gerdts E, Dahlöf B, Aalto $\mathrm{T}$, et al. Impact of different partition values on prevalence of left ventricular hypertrophy and concentric geometry in a large hypertensive population: the LIFE study. Hypertension 2000; 35: 6-12.

13. Devereux RB, Palmieri V, Sharpe N, De Quattro V, Bella JN, de Simone G, et al. Effects of once-daily angiotensin- converting enzyme inhibition and calcium channel blockade- based antihypertensive treatment regimens on left ventricular hypertrophy and diastolic filling in hypertension. The Prospective Randomized Enalapril Study Evaluating Regression of Ventricular Enlargement (PRESERVE) trial. Circulation 2001; 104: 1248-54.

14. Mosterd A, D'Agostino RB, Silbershatz H, Sytkowski PA, Kannel WB, Grobbee DE, et al. Trends in the prevalence in hypertension, antihypertensive therapy and left ventricular hypertrophy from 1950 to 1989 . N Eng J med 1999; 340: 1221-7.

15. Doba N, Tomiyama H, Vashida H. Left ventricular hypertrophy in mild essential hypertension, its progression, prediction and treatment strategy. Japan Heart J 1996; 37: 417-30.

16. Gardin JM, Savage DD, Ware JH, Henry WL. Effects of age, sex and body surface area on echocardiographic left ventricular wall mass in normal subjects. Hypertension 1987; 19 Suppl 2: 36-41.

17. Varagic J, Susic D, Frochlich E. Heart, aging and hypertension. Curr Opin Cardiol 2001; 16: 336-41.

18. Armario P, Hernández del RR, Martín-Baranera M, Andreu-Valls N, Ceresuela LM, Pardell H. The effect of age on the relationship of pulse pressure and left ventricular mass in untreated patients with mild to moderate hypertension. Blood Press 2002; 11: 13-7.

19. Devereux RB, de Simone G, Ganau A, Roman MJ. Left ventricular hypertrophy and geometric remodeling 
in hypertension: stimuli, functional consequence and prognostic implications. J Hypertension 1994; 12 Suppl: S117-27.

20. Savage DD, Garrison RJ, Kannel WB, Levy D, Anderson SJ, Stokes J 3rd, et al. The spectrum of left ventricular hypertrophy in a general population sample: the Framingham study. Circulation 1987; 75 Suppl I: 26-33.

21. Conrady AO, Rudomanov OG, Zaharov DV, Krutikov AN, Vahrameeva NV, Yakovleva OI, et al. Prevalence and determinants of left ventricular hypertrophy and remodeling patterns in hypertensive patients: the St. Petersburg Study. Blood Press 2004; 13: 101-9.

22. Saba MM, Ibrihim MM, Rizk HH. Gender and relationship between resting heart rate and left ventricular geometry. J Hypertens 2001; 19: 367-73.

23. Missault LH, De Buyzere ML, De Bacquer DD, Duprez DD, Clement DL. Relationship between left ventricular mass and blood pressure in treated hypertension. Hum Hypertens 2002; 16: 61-6.

24. Chen CH, Ting CT, Lin SJ, Hsu TL, Ho SJ, Chou P, et al. Which arterial and cardiac parameters best predict left ventricular mass? Circulation 1998; 98: 422-8.

25. Gharavi AG, Diamond JA, Goldman AY, Coplan NL, Jhang JS, Steinmetz M, et al. Resting diastolic function and left ventricular mass are related to exercise capacity in hypertensive men but not in women. Am J Hypertens 1998; 11: 1252-7.

26. Cuocolo A, Sax FL, Brush JE, Maron BJ, Bacharach SL, Bonow RO. Left ventricular hypertrophy and impaired diastolic filling in essential hypertension. Diastolic mechanisms for systolic dysfunction during exercise. Circulation 1990; 81: 978-86.

27. Gardin JM, Siscovick D, Anton-Culver H, Lynch JC, Smith VE, Klopfenstein HS, et al. Sex, Age, and Disease Affect Echocardiographic Left Ventricular Mass and Systolic Function in the Free-Living Elderly. Circulation 1995; 91: 1739-48.

28. Hanevold C MD, Waller J PhD, Daniels S MD PhD, Portman R MD, Sorof J MD. The Effects of Obesity, Gender, and Ethnic Group on Left Ventricular Hypertrophy and Geometry in Hypertensive Children: A Collaborative Study of the International Pediatric Hypertension Association. Pediatrics 2004; 113 (2): 328-33.

29. Muiesan ML, Rizzoni D, Salvetti M, Porteri E, Monteduro C, Guelfi D, et al. Structural changes in small resistance arteries and left ventricular geometry in patients with primary and secondary hypertension. Journal of Hypertension 2002; 20: 1439-44. 